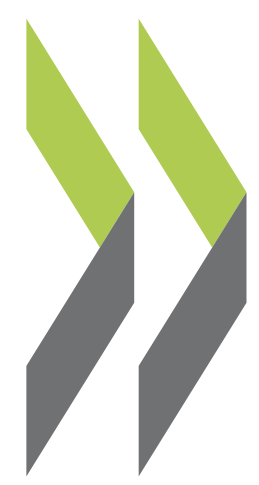

OECD Social, Employment and Migration Working Papers No. 16

\title{
The Swedish Activity Guarantee
}

\section{Anders Forslund, \\ Daniela Froberg, \\ Linus Lindqvist}


The Swedish Activity Guarantee

Anders Forslund, Daniela Froberg and Linus Lindqvist

\section{6}


Organisation de Coopération et de Développement Economiques

Organisation for Economic Co-operation and Development

22-Jan-2004

DIRECTORATE FOR EMPLOYMENT, LABOUR AND SOCIAL AFFAIRS

English - Or. English

EMPLOYMENT, LABOUR AND SOCIAL AFFAIRS COMMITTEE

OECD SOCIAL, EMPLOYMENT AND MIGRATION WORKING PAPER NO. 16

THE SWEDISH ACTIVITY GUARANTEE

Anders Forslund,* Daniela Froberg ${ }^{\circ}$ and Linus Lindqvist $^{\circ}$

JEL Classification: J64, J65, J68

*IFAU and Department of Economics, Uppsala University

${ }^{\circ} I F A U$

JT00157054

Document complet disponible sur OLIS dans son format d'origine

Complete document available on OLIS in its original format 


\title{
OECD SOCIAL, EMPLOYMENT AND MIGRATION WORKING PAPERS
}

This series is designed to make available to a wider readership selected labour market, social policy and migration studies prepared for use within the OECD. Authorship is usually collective, but principal writers are named. The papers are generally available only in their original language - English or French with a summary in the other.

Comment on the series is welcome, and should be sent to the Directorate for Employment, Labour and Social Affairs, 2, rue André-Pascal, 75775 PARIS CEDEX 16, France.

The opinions expressed and arguments employed here are the responsibility of the author(s) and do not necessarily reflect those of the OECD

\author{
Applications for permission to reproduce or translate \\ all or part of this material should be made to: \\ Head of Publications Service \\ OECD \\ 2, rue André-Pascal \\ 75775 Paris, CEDEX 16 \\ France
}

Copyright OECD 2004 
DELSA/ELSA/WD/SEM(2004)1

\section{SUMMARY}

1. Until recently, an unemployed person in Sweden who participated in an active labour market programme earned entitlement to a further 60 weeks of unemployment insurance (UI) benefits. A "carousel" effect - cycling between periods of open unemployment and participation in active programmes - increasingly seen came to be seen as a factor making the active programmes less effective in promoting the transition to ordinary work. Following policy reforms in 2000 and 2001, participation in a programme no longer generates new UI entitlements. However, the public employment service (PES) can refer the unemployed to a new programme, the Activity Guarantee. This provides continuing income support, and engages participants in job-search and other activities in principle full-time until they find ordinary work.

2. This paper summarises findings from two questionnaire surveys of the implementation of the Activity Guarantee. The first survey was addressed to PES case workers, who have direct personal contact with participants and much of the responsibility for designing programme content. The second survey was addressed to participants, and reports on their personal characteristics and job search activity, and their experience of the programme and views about its effectiveness.

3. Many case workers thought that information concerning the content of the Activity Guarantee was not sufficiently clear, and that they had not received sufficient training for this work. Existing guidelines were not always implemented: contrary to quality criteria, case workers on the programme often had other work assignments, and almost one quarter of PES offices did not offer programme participants a full-time activity. A common method of implementing the programme was to first engage participants in job-search activities for groups, and later offer a place on a regular labour market programme.

4. Participants in the Activity Guarantee have the usual characteristics of the long-term unemployed: a relatively high mean age, a relatively high share with a disability, and a low level of training. On the whole, survey respondents were content with the programme. However, almost half were critical of the activities offered and more than half said they would not participate if it did not provide them with income. Two-thirds reported that they were activated full-time. However, only slightly more than half met their supervisor as often as once a month. Fewer had applied for a job within the last four weeks, or knew that they had an individual action plan. Since 2001, benefit recipients must widen their geographic and occupational areas of job search after 100 days of unemployment, and supervisors had recommended nearly three-fifths of respondents to widen their occupational search area, and one-fifth to widen their geographic search area. However, there were no clear signs that job-search activity had increased among the participants. 


\section{RÉSUMÉ}

5. En Suède, jusqu'à une date récente, le fait, pour un chômeur, à un programme actif du marché du travail ouvrait droit à une nouvelle période d'assurance chômage (AC) de 60 semaines. Un effet de "carrousel" - passages répétés entre des périodes de chômage "simple" et des périodes de participation à un programme actif - a progressivement fait que les programmes promouvaient moins efficacement la transition vers un emploi ordinaire. Suite à des réformes introduites en 2000 et 2001, la participation dans un programme ne permet plus d'acquérir de nouveaux droits à l'AC. Le Service public de l'emploi (SPE) peut néanmoins admettre les chômeurs à un nouveau programme, la "Garantie d'activité". Ce programme les engage dans des activités de recherche d'emploi et autres, en principe à temps complet, jusqu'à l'obtention d'un travail ordinaire.

6. La présente étude résume les résultats de deux enquêtes concernant la mise en oeuvre de ce nouveau programme. La première enquête a été adressée aux conseillers du SPE, qui ont des contacts directs avec les participants et qui, pour une large part, déterminent le contenu du programme. La deuxième enquête a été adressée aux participants et elle décrit leurs caractéristiques personnelles, leurs activités de recherche d'emploi, leurs expériences du programme et leurs avis concernant l'efficacité de ce dernier.

7. Beaucoup de conseillers du SPE estimaient que l'information sur le contenu de la Garantie d'activité n'était pas assez claire, et qu'ils n'avaient pas reçue une formation adéquate pour ce travail. Les lignes directrices existantes n'étaient pas toujours suivies : contrairement aux critères de qualité, les conseillers du programme avaient souvent d'autres tâches, et presque le quart des agences du SPE ne proposait pas une activité a plein temps. La mise en œuvre du programme s'effectuait souvent, d'abord par des activités de recherche d'emploi en groupes, et ensuite, par l'orientation vers un programme actif classique du marché du travail.

8. Les participants à la Garantie d'activité ont les caractéristiques habituels des chômeurs de longue durée : un âge moyen relativement élevé, une part relativement importante d'entre eux souffre d'un handicap et/ou ont un bas niveau de formation. La plupart des personnes sondées étaient satisfaits du programme. Pourtant, près de la moitié d'entre elles critiquait les activités proposées et la majorité affirmait qu'elles n'auraient pas participé si le programme n'apportait pas un revenu. Les deux tiers était "activés" à plein temps. Pourtant, guère plus que la moitié rencontraient leur conseiller une fois ou plus par mois. La proportion de personnes conscientes d'avoir un projet personnalisé pour le retour à l'emploi, ou ayant postulé à un emploi pendant les quatre dernières semaines, était moindre. Depuis 2001, les allocataires doivent élargir leur champ géographique et occupationnel de recherche d'emploi après 100 jours au chômage. Les conseillers avaient recommandé à presque trois personnes sondées sur cinq d'élargir leur champ occupationnel de recherche et à une sur cinq d'élargir leur champ géographique de recherche. Mais il n'y avait pas d'indice clair d'une augmentation des activités de recherche d'emploi chez les participants. 
TABLE OF CONTENTS

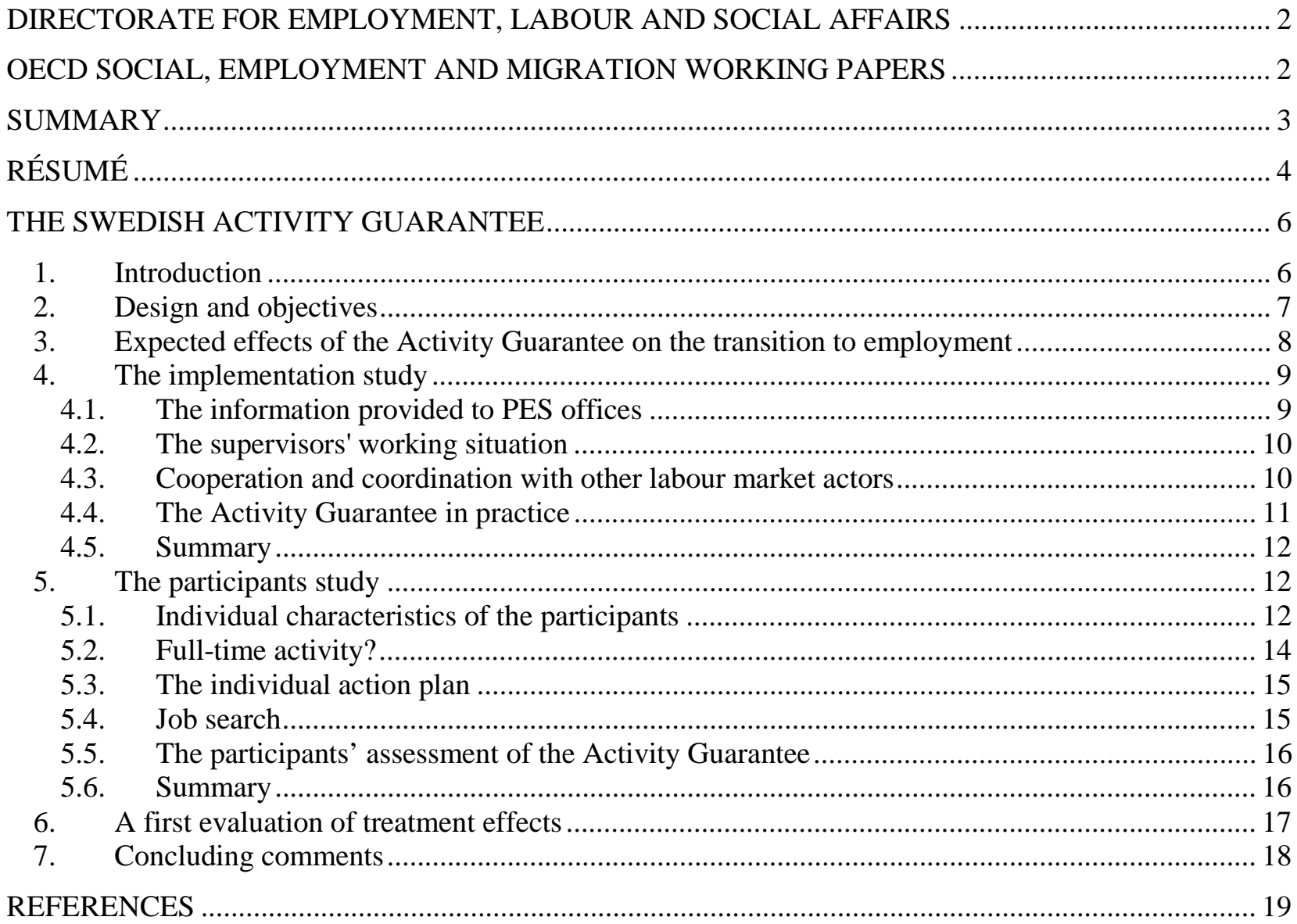

\section{Tables}

Table 1. Participants in the Activity Guarantee ${ }^{a}$ by duration of uninterrupted registration at the PES just

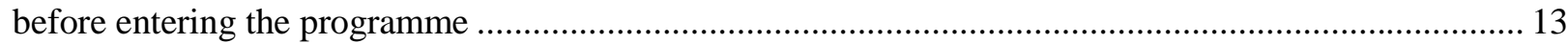
Table 2. Participants in the Activity Guarantee ${ }^{a}$ by the duration of their uninterrupted registration at the PES including their time in the programme .................................................................................... 14 Table 3. All registered job-seekers ${ }^{a}$ by the duration of their latest registration spell at the PES .............. 14 


\section{THE SWEDISH ACTIVITY GUARANTEE ${ }^{1}$}

\section{Introduction}

9. The interaction between unemployment insurance (UI) and active labour market programmes (ALMPs) has been an issue in the Swedish policy discussion for at least a decade. On the one hand, UI benefit payments have had a limited duration (300 days). On the other hand, ALMPs have since the late 1980s provided their participants with eligibility for a new period of UI benefits after completion of participation in the programme. ${ }^{2}$ This has potentially had detrimental incentive effects both for the UI system and ALMPs. ${ }^{3}$ Reforms in the UI system and ALMPs have now changed the rules of the game. First, participation in ALMPs no longer renews UI benefit eligibility. Second, UI benefit eligibility can be at administrative discretion be extended at most once, i.e. up to a total of 600 days. Third, to provide the long-term unemployed with income support and at the same time to promote their job-search efforts, a new labour market programme, the Activity Guarantee, was introduced in August 2000. The government decision to start the programme was inter alia based on a report from the National Labour Market Board (AMS: in English, LMB) and a number of reports from government committees (see for example Ams, 1999; Ds 1999:54; Ds 1999:58). The Activity Guarantee is not a labour market programme in the same sense as, for example, labour market training; rather, it is a framework within which the participant can take part in different programmes (possibly sequences of programmes) or engage in different job-search activities.

10. IFAU (The Institute for Labour Market Policy Evaluation) was commissioned by the Swedish government to follow up and, if possible, to evaluate the Activity Guarantee. The results of these efforts have been presented in two reports from the institute (Fröberg and Persson, 2002; Fröberg and Lindqvist, 2002) which are available only in Swedish. ${ }^{4}$ The first report focuses on the implementation of the reform, while the second report primarily presents information based on questionnaires distributed to participants.

11. In the present paper Sections 2 and 3 describe the design and objectives of the Activity Guarantee and analyse its expected effects, Section 4 summarises findings from the report on implementation, and Section 5 summarises findings from the participant survey. Section 6 briefly presents the results of an evaluation study performed at the National Labour Market Board, and describes some problems of evaluating the programme. Finally, based on the material presented in the paper, concluding comments discuss to what extent the programme can be expected to provide an efficient solution to previous problems in Swedish ALMPs/UI.

1. Comments from David Grubb are gratefully acknowledged.

2. Participation in programmes considered "work", if the duration was sufficient, gave renewed benefit eligibility already earlier than the late 1980s.

3. Cross-country studies indicate that UI benefits with a limited duration contribute to lower unemployment rates (see e.g. Layard et al. 1991). A number of evaluation studies suggest that part of the disappointing effects of Swedish ALMPs in the 1990s may be attributed the fact that programmes partly were used to renew UI benefit eligibility, cf. e.g. Sianesi (2001a, 2001b) and Calmfors et al. (2001).

4. The two reports are follow-up reports; problems of finding an adequate control group for an evaluation have hence far not been solved. 


\section{Design and objectives}

12. The overall target for the Activity Guarantee is to improve the participants' labour market situation and to stop them from becoming marginalised. There are also a number of sub-targets. First, the government seeks to provide the participants with more job-search assistance (Government Bill 1999/2000:139). Second, there is a general preference for work or programme participation rather than "passive" UI benefit collection. A third sub-target is to develop methods to activate groups of job-seekers with a weak position in the labour market. Finally, the Activity Guarantee was designed to break up the cycling between open unemployment and programme participation in which many individuals got caught during the 1990s (Government Bill 1999/2000:98).

13. The Activity Guarantee was inaugurated in August 2000. It was preceded by a short pilot scheme that came in to action in April-May 2000 at selected PES offices in all of the 21 Swedish counties. The experiences from the scheme were gathered in June by a special project group at the LMB and used as information material when the programme was to be implemented in full scale. The new UI benefit payments rules, according to which programme participation no longer qualifies for renewed UI benefit eligibility, were inaugurated in February 2001, six months after the introduction of the Activity Guarantee (Government Bill 1999/2000:139).

14. The target group for the Activity Guarantee is persons who are or are at risk of becoming longterm registered at the Public Employment Service (PES) or those whose unemployment benefit eligibility is about to run out. Participation is supposed to imply full-time activity and the participants receive the equivalent of unemployment benefits. The Activity Guarantee is a framework within which all regular labour market measures can be used. The participant is supposed to be engaged in job search, a labour market programme or in studies. The activities are supposed to be full time. ${ }^{5}$

15. A participant can only leave the programme in three ways: by working in a regular job for at least six months, by starting to participate in regular education ${ }^{6}$ or by leaving the labour force. Hence, programme duration is indefinite; the participant will have access to all facilities of the PES as long as it is "motivated from a labour market policy perspective" (Government Bill 1999/2000:98).

16. The participants should, according to the government bill, be subdivided into groups of 10-15 persons. The LMB has instead recommended groups of 25-30 persons (Ams, 2001). The group activities should, according to suggestions from the LMB, be organised by the local PES office and be led by a PES case worker. The idea is that organised job search should be the basis of the activities at the PES office (Ams, 1999; Government Bill 1999/2000:98).

17. The case workers who implement the Activity Guarantee are called supervisors. Through the activities they get to know "their" participants, together with whom they should prepare individual action plans. The idea is that this action plan should govern which activities the participant is engaged in within the Activity Guarantee. Upon completion of each such activity (or at least once every six months), the action plan should be updated and, if necessary, revised (Government Bill 1999/2000:98).

18. In addition to the regular supply of programmes, firms, municipalities and other authorities can arrange activities. A necessary condition is that they have reached a formal agreement with the county

5. $\quad$ "Full-time" is defined in terms of desired labour supply. An individual whose desired labour supply is stated to be $100 \%$, but who is on part-time sick leave, is supposed to participate full time minus the percentage of time on sick leave.

6. According to Ordinance 2000:634, this refers to education which gives eligibility to government study allowance. 
labour market board. However, the PES office still has the full responsibility for the activities and for monitoring the participants' job search.

\section{Expected effects of the Activity Guarantee on the transition to employment}

19. What distinguishes the Activity Guarantee from other ALMPs (assuming that it works according to intentions) are three main features: increased job-search assistance (counselling), increased monitoring ${ }^{7}$ and an indefinite duration.

20. Applying search theory, we can predict the consequences of each of these three. ${ }^{8}$ The indefinite duration is most straightforward. This is most easily seen by comparing to a UI benefit system with a fixed duration. In such a system, the reservation wage will fall when the unemployed gets closer to the time of benefit exhaustion. This will be accompanied by an increasing transition rate to employment. Absent a time limit for UI benefits, this increased hazard to employment will also be absent, and hence we should expect a system with unlimited benefit duration to be characterised by a lower hazard to employment. However, if we compare to the previous Swedish system with its possibilities of cycling between UI benefit periods and programme participation, the effective change seems minor. ${ }^{9}$

21. The effects of counselling and monitoring are analysed in van den Berg and van der Klaauw (2001). In their analysis, they allow the unemployed individual to search along both formal and informal search channels. ${ }^{10}$ Counselling will, in their analysis, increase the efficiency of formal search. This will result in a higher job offer arrival rate, but also in a higher reservation wage. An increased efficiency of formal job search will also induce individuals to substitute formal for informal search. Van den Berg and van der Klaauw show that under rather general conditions, "...the rate at which the individual leaves unemployment by way of the formal (informal) channel increases (decreases), and that the first effect dominates...". Monitoring is assumed to concern formal search. To the extent that the required formal search effort is higher than in the absence of monitoring, the response will be substitution away from informal to formal search, but in this case without an accompanying increase in search efficiency. The net effect on the transition to employment is in general ambiguous. The probability of a positive effect on the hazard to employment is higher the lower is the initial level of informal search. ${ }^{11}$ Evidence on search behaviour among the long-term Swedish unemployed, collected by the LMB using survey methods, however, suggests that informal search has played an important role also among the longterm unemployed. ${ }^{12}$

22. To summarise: on balance, increased counselling would be expected to increase the transition rate to work, whereas increased monitoring would have uncertain effects. Given this, we would à priori

7. This is inter alia a consequence of the fact that the activities are supposed to be full-time.

8. Basic results of search theory on how UI compensation affects job search can be found in Mortensen (1977). Fredriksson and Holmlund (2003) is a useful survey of the incentive effects of the design of UI systems in a number of dimensions.

9. However, both Carling et al. (1996) and Carling et al. (2001) found that exit to employment increased for workers who had come close to benefit exhaustion.

10. Formal search is basically search through the PES, whereas informal search is everything else, for example search using social networks.

11. If the level of informal search is low already before the increase in monitoring, there are small substitution possibilities. In the limiting case where there is no initial informal search, the effect will be an increase in formal search only.

12. For example, in the first quarter of 2001, more than two thirds of the respondents who had found a job stated that the search channel was not the PES (Hägglund, 2002). 
expect the effect of the Activity Guarantee on the transition to work to reflect the relative importance of counselling and monitoring in the programme. These theoretical predictions are consistent with experimental evidence from the US and the Netherlands (Meyer, 1995; Ashenfelter et al., 1999; van den Berg and van der Klaauw, 2001).

\section{The implementation study}

23. The IFAU report presented in this section (Fröberg and Persson, 2002) is an implementation study and, as such, a study of the Swedish National Labour Market Administration's (LMA) implementation of the Activity Guarantee. Four areas have been given particular attention: First, the diffusion of information within the LMA; second, the situation of case workers working with the programme; third, the co-ordination and co-operation between the PES offices and external agents; and finally, what we have chosen to call the Activity Guarantee in practice. Information has been gathered mainly through questionnaires directed to LMA-employees, but also partly from interviews. ${ }^{13}$

\subsection{The information provided to PES offices}

24. What makes it interesting to analyse the diffusion of information to the PES offices? The primary reason is that the case workers cannot realise political intentions without knowledge of what the intentions are. To ease the implementation process, the information received should be relevant and explicit. However, the information does not necessarily have to be detailed: case workers should ideally be given some freedom to apply the regulations according to experience - especially in an area like labour market policy where individual adaptation is of importance. However, individuals should not be treated differently depending on which PES office they enter or which case worker they meet with: they ought (to a reasonable extent) to be treated equally.

25. According to 58\% of the supervisors, the information received about the Activity Guarantee was not fully sufficient. One aspect that was rather unclear was what the Activity Guarantee was supposed to consist of. Those decisions were intentionally left to case workers at a local level to a rather large extent. The importance of full-time activities as well as organised job-search activities and activities for groups of job-seekers was stressed. But within a certain framework the case workers were free to design the content to fit their particular participants and were meant to rely on their experience. A consequence of this management approach was, however, that supervisors at a fairly large number of PES offices found it difficult to know how to design the programme in practice. The LMB had decided to develop quality indicators to raise the quality above a certain minimum level about six months after the programme startup.

26. IFAU has carried out follow-ups of the implementation of different ALMPs on several occasions (see, for example, Lundin 2000, 2001). Some of the questions asked have been the same, making a comparison between the results possible. Such a comparison reveals that the case workers were more uncertain about which job-seekers to assign to the Activity Guarantee than about which job-seekers were eligible for employment subsidies. It should, however, not be forgotten that the Activity Guarantee is a special kind of framework programme: the participants can take part in all the other ALMPs within this framework. When selecting participants for the Activity Guarantee, the requirements are that the job-

13. The results presented here are based on a questionnaire addressed to the supervisors working at the PES offices. The response rate was $81 \%$ (in terms of the offices). Supervisors at six PES offices and case workers at the County Labour Market Board in three counties in different parts of Sweden were interviewed. A second questionnaire was directed to case workers at the County Labour Market Boards as an attempt to follow the implementation process; those results will, however, not be presented in this summary. 
seekers have been registered as unemployed for a long time period and are in need of more extensive help from the labour market authorities. This last prerequisite requires a subjective assessment from the local case workers. In 2001 the LMB wanted the County Labour Market Boards and the PES offices to develop a formal instrument for the selection of participants, but the latter deemed it unnecessary.

\subsection{The supervisors' working situation}

27. The supervisors at the PES offices play an important part in the implementation process. First, they have direct personal contacts with participants. Second, their authoritative role has been strengthened since participants are supposed to see their supervisors regularly and more often than before entering the programme. The supervisors find out more about the participants and are supposed to monitor their job search more actively. Third, as the results from the earlier section shows, supervisors have had little guidance: they are supposed to design the Activity Guarantee in practice. This increased their importance for implementation even more, and therefore made our interest in their working situation even greater.

28. Using information collected from the LMA's databases and our questionnaire, we calculated a rough measure of supervisor density. Each supervisor was responsible for 37 participants, on average. According to recommendations from the LMB the participants should take part in activities in groups of 25-30 persons. Note that our measure of supervisor density is not a measure of the group size, since participants do not take part in group activities during their entire participation period. They can also take part in all programmes available at the PES offices and in activities arranged by the offices' different partners. Supervisor density should therefore be regarded as an indicator of how close the contacts between supervisors and participants could reasonably be.

29. One of the quality criteria set up by the LMB was that case workers working with the programme could give it their full attention. It is, however, common for the supervisors to have other assignments apart from working with the Activity Guarantee. At almost half the PES offices all supervisors had other assignments. There was a clear difference between offices in different parts of the country: in metropolitan counties it was more common for supervisors to work exclusively with the Activity Guarantee than in nonmetropolitan ones.

30. Another aspect of the case workers' situation is their competence in working with groups of longterm unemployed: just over $41 \%$ claimed that the case workers at their PES had not received sufficient training for working with the Activity Guarantee.

\subsection{Cooperation and coordination with other labour market actors}

31. Cooperation between the PES offices and actors outside the LMA is a means to establish contact between participants and employers and to ensure that the participation is a full-time activity. Additionally, the agreements make it possible for participants to take part in other activities than the ALMPs traditionally available.

32. According to our questionnaire, municipalities are the PES offices' most frequent partners: 68\% of the offices have signed an agreement with a municipality. One reason for this could be that the labour market authorities and the local communities have cooperated quite extensively during the labour market crisis in the 1990s. Agreements with private firms, non-profit organisations, or other government agencies are far less common. Cooperation between PES offices and private firms is much more frequent in metropolitan counties than in non-metropolitan ones. 


\subsection{The Activity Guarantee in practice}

33. The Activity Guarantee serves a dual purpose: the programme is supposed to entail intensified support for the job-seekers, but at the same time the labour market authorities' control over the participants should be strengthened.

34. Labour market programmes no longer provide participants with renewed eligibility for UI benefit payments. Instead, persons not able to find a job before benefit exhaustion should be assigned to the Activity Guarantee or be granted benefit payments for an additional period of time. Job-seekers in special need of assistance in finding a job are to be assigned to the programme, but if a job-seeker is likely to find a job on his or her own, that person will instead be granted a further period of UI benefit payments, ${ }^{14}$ so that benefits can be paid for 600 instead for 300 days. ${ }^{15}$ Case workers at PES offices are the ones who assess which job-seekers risk running out of benefits.

35. How common has the extension of UI benefits been in practice? We have no data on UI spells. Instead, we have used information on the duration of spells in open unemployment registered at the PES to compute the share of spells in open unemployment that have been extended from 420 days to 840 after the introduction of the Activity Guarantee. These computations reveal that between 6\% and 7\% of the spells were extended in this way. Hence, although the fraction is small, it is by no means negligible. Almost $5 \%$ had spells in open unemployment that even lasted at least 900 days. Using the same register data, we also see that after 1 August, 2000, only slightly less than 4500 of the 52500 persons who had been openly unemployed for at least 420 days entered the Activity Guarantee. In this sense, the name of the programme may be a slight misnomer.

36. We have also computed the fraction of persons with a total register spell of at least 2 years that actually participated in the Activity Guarantee in the period after August 2000. This share was well below $3 \%$. If job-seekers who were part-time unemployed, employed by the hour or job changers are excluded, the fraction was instead around $4 \%$. On this basis, the majority (almost 60\%) of those with register spells exceeding 2 years participated in various other labour market programmes.

37. During 2001, persons who had exhausted their UI benefit payments came to dominate among the new participants of the Activity Guarantee - especially in metropolitan counties. According to the supervisors we interviewed, this was sometimes to the disadvantage of people in greater need of assistance from the labour market authorities. In the metropolitan counties the share of the case workers thinking the job-seekers assigned to the Activity Guarantee were those in need of the programme was substantially smaller than in the non-metropolitan counties.

38. When asked how they had principally designed the programme in practice a majority answered that they began with group activities, for example job search. Later the participants would take part in other labour market programmes or activities arranged by partners of the PES offices. However, at almost a quarter of the PES offices the participants were not offered a full-time activity. When asked why, the great majority of supervisors answered that they were not sufficiently staffed to perform the task.

14. Job-seekers can however be assigned to the Activity Guarantee whenever the case workers at a PES office deems it appropriate.

15. In this context, 300 days is roughly equivalent to 420 days in calendar time, since benefits are paid five days a week. 


\subsection{Summary}

39. Central guidelines for the Activity Guarantee have not been very detailed or comprehensive. The design of the programme has therefore, to a large extent, been worked out at the local level. This entails, on the one hand, great flexibility and consequently room for adaptation to the participants' individual needs. On the other hand, it involves a risk that participants are not treated equally.

\section{The participants study}

40. The second report from IFAU (Fröberg and Lindqvist, 2002) is a follow up-study which primarily focuses on the participants of the Activity Guarantee. It describes individual characteristics of the participants, such as age, sex and level of education, as well as their time in the programme, their opinion of the programme and their assessment of the employment office. The main objective of the report is thus to describe the participants as well as the programme from their perspective. The programme's output is measured in a number of respects: Which job-seekers have participated in practice? What is the participants' conception of the services of the PES offices and the activities they have taken part in? How intensively do participants search for a job? And finally, what is their assessment of the Activity Guarantee as a whole?

41. The main source of information is a questionnaire directed to programme participants. In February 2002, 36000 persons participated in the Activity Guarantee. The questionnaire was directed to a random sample of 5000 of these participants $-76 \%$ of whom answered. To describe the participants in the Activity Guarantee with respect to their individual characteristics we studied all persons (approximately 60 000) who, on at least one occasion, had participated in the Activity Guarantee since the start of the programme in August 2000 until April 2002. This description is based on LMB data.

\subsection{Individual characteristics of the participants}

42. To facilitate interpretation of the participants' valuation of the programme, it is essential to know something about their average individual characteristics. Tables 1 and 2 below describe persons who had participated in the Activity Guarantee up until April 2002. Table 3 describes a comparison group made up of all persons who had been registered as unemployed at the PES offices at least on one occasion from the start of the programme until October 2002.

43. Among the participants the proportion of women is lower (44\%, compared with $52 \%$ among all registrants) and the mean age is higher (46 years, compared to 37 years). The participants' average level of education is lower ( $16 \%$ have some form of tertiary education, compared with $22 \%$ among all registrants) and the proportion with a work-related disability is higher (22\% compared with $14 \%$ ). These results were expected, since the target group of the programme was persons who had been unemployed for a long time. Earlier studies have shown that a higher age and a lower level of education decrease a job-seeker's chance of getting a job (Thoursie, 1998; van den Berg and Richardson, 2002). 
DELSA/ELSA/WD/SEM(2004)1

Table 1. Participants in the Activity Guarantee ${ }^{a}$ by duration of uninterrupted registration at the PES just before entering the programme

\begin{tabular}{|c|c|c|c|c|c|c|}
\hline & $\begin{array}{c}\text { Less than a } \\
\text { year }\end{array}$ & $1-2$ years & 2-3 years & 3-4 years & $>4$ years & Total \\
\hline Women & $47 \%$ & $45 \%$ & $45 \%$ & $43 \%$ & $42 \%$ & $44 \%$ \\
\hline Work related disability & $19 \%$ & $21 \%$ & $22 \%$ & $24 \%$ & $30 \%$ & $22 \%$ \\
\hline Non-Nordic participants & $11 \%$ & $10 \%$ & $10 \%$ & $8 \%$ & $7 \%$ & $9 \%$ \\
\hline Compulsory school & $32 \%$ & $33 \%$ & $33 \%$ & $36 \%$ & $42 \%$ & $36 \%$ \\
\hline $\begin{array}{l}\text { Upper secondary school } \\
\text { education }\end{array}$ & $53 \%$ & $51 \%$ & $52 \%$ & $48 \%$ & $44 \%$ & $49 \%$ \\
\hline $\begin{array}{l}\text { Post-secondary school } \\
\text { level of education }\end{array}$ & $15 \%$ & $16 \%$ & $15 \%$ & $17 \%$ & $14 \%$ & $16 \%$ \\
\hline Mean age & 40 years & 44 Years & 46 years & 48 Years & 51 Years & 46 Years \\
\hline $\mathrm{N}$ & $\begin{array}{l}14400 \\
(26 \%)\end{array}$ & $\begin{array}{l}9643 \\
(17 \%)\end{array}$ & $\begin{array}{l}8021 \\
(14 \%)\end{array}$ & $\begin{array}{l}4649 \\
(8 \%)\end{array}$ & $\begin{array}{l}19639 \\
(35 \%)\end{array}$ & $\begin{array}{l}56352 \\
(100 \%)\end{array}$ \\
\hline
\end{tabular}

a) All persons who participated between August 2000 and April 2002, with no consideration as to whether they left the programme or not.

44. A more detailed picture of the participants is given by the breakdown of data by duration of registration at the PES in Tables 1 to $3 .^{16}$ Looking at the inflow into the Activity Guarantee, we see that, as expected, the long-term unemployed (those with a long pre-guarantee register spell) are clearly over represented in comparison with the universe of job-seekers. However, a sizeable fraction (26\%) of the entrants have spent less than a year in the PES registers before entering the guarantee.

16. Duration of registration at the PES includes periods of participation in different ALMPs. A register spell is ended when a person leaves the PES. This happens if the person finds a job or if the PES loses contact with him/her for any reason. 
Table 2. Participants in the Activity Guarantee ${ }^{a}$ by the duration of their uninterrupted registration at the PES including their time in the programme

\begin{tabular}{c|cccccc}
\hline & $\begin{array}{c}\text { Less than a } \\
\text { year }\end{array}$ & $1-2$ years & $2-3$ years & $3-4$ years & $>4$ years & Total \\
\hline Women & $48 \%$ & $46 \%$ & $45 \%$ & $44 \%$ & $42 \%$ & $44 \%$ \\
Work related disability & $16 \%$ & $19 \%$ & $23 \%$ & $23 \%$ & $29 \%$ & $22 \%$ \\
Non-Nordic participants & $11 \%$ & $10 \%$ & $10 \%$ & $10 \%$ & $7 \%$ & $9 \%$ \\
Compulsory school & $31 \%$ & $32 \%$ & $33 \%$ & $32 \%$ & $41 \%$ & $36 \%$ \\
Upper secondary school education & $53 \%$ & $53 \%$ & $52 \%$ & $51 \%$ & $44 \%$ & $49 \%$ \\
Post secondary school level of education & $16 \%$ & $15 \%$ & $15 \%$ & $16 \%$ & $15 \%$ & $16 \%$ \\
Mean age & & & & & & \\
N & 39 Years & 42 Years & 45 Years & 46 Years & 51 Years & 46 Years \\
& 7574 & 9732 & 8754 & 6325 & 23967 & 56352 \\
$(13 \%)$ & $(17 \%)$ & $(16 \%)$ & $(11 \%)$ & $(43 \%)$ & $(100 \%)$ \\
\hline
\end{tabular}

a) With the same coverage as Table 1.

Table 3. All registered job-seekers ${ }^{a}$ by the duration of their latest registration spell at the PES

\begin{tabular}{|c|c|c|c|c|c|c|}
\hline & $\begin{array}{c}\text { Less than a } \\
\text { year }\end{array}$ & $1-2$ years & $2-3$ years & $3-4$ years & $>4$ years & Total \\
\hline Women & $51 \%$ & $55 \%$ & $58 \%$ & $59 \%$ & $50 \%$ & $52 \%$ \\
\hline Work related disability & $5 \%$ & $14 \%$ & $21 \%$ & $26 \%$ & $48 \%$ & $14 \%$ \\
\hline $\begin{array}{l}\text { Non-Nordic } \\
\text { participants }\end{array}$ & $8 \%$ & $11 \%$ & $10 \%$ & $8 \%$ & $6 \%$ & $8 \%$ \\
\hline Compulsory school & $23 \%$ & $28 \%$ & $31 \%$ & $31 \%$ & $43 \%$ & $27 \%$ \\
\hline $\begin{array}{l}\text { Upper secondary } \\
\text { school education }\end{array}$ & $52 \%$ & $51 \%$ & $54 \%$ & $55 \%$ & $44 \%$ & $51 \%$ \\
\hline $\begin{array}{l}\text { Post secondary school } \\
\text { level of education }\end{array}$ & $25 \%$ & $21 \%$ & $15 \%$ & $14 \%$ & $11 \%$ & $22 \%$ \\
\hline Mean age & 34 years & $\begin{array}{r}39 \\
\text { years }\end{array}$ & 42 years & 44 years & 49 years & 37 years \\
\hline $\mathrm{N}$ & $\begin{array}{l}604939 \\
(61 \%)\end{array}$ & $\begin{array}{l}138538 \\
(14 \%)\end{array}$ & $\begin{array}{l}64273 \\
(7 \%)\end{array}$ & $\begin{array}{l}34493 \\
(4 \%)\end{array}$ & $\begin{array}{l}134401 \\
(14 \%)\end{array}$ & $\begin{array}{l}976644 \\
(100 \%)\end{array}$ \\
\hline
\end{tabular}

a) All persons who on at least one occasion between August 2000 and October 2002 had been registered as unemployed at the PES

\subsection{Full-time activity?}

45. Two-thirds (66\%) of the participants said that they had been activated full time during their time in the programme. A problem with the activities offered was that almost half of the participants were critical due to a lack of individual adjustment and lacking meaningfulness. 
46. When a person started participating in the Activity Guarantee, a common way of working at the employment offices was to initially offer job-search activities for groups and later on offer a labour market programme. This implies a closer contact between job-seeker and supervisor during the beginning of the participation. According to the results from the questionnaire, the participants met with their supervisor more often during their first months in the programme. However, the contact frequency seems to have been low on average: almost half of the participants met their supervisor less than once a month. This result could partly be explained by participation in other activities. However, for one-third of the participants that met with their supervisor less than once a month, the counselling and placement services were the listed activities. These activities should imply more frequent meetings between the job-seeker and the supervisor.

\subsection{The individual action plan}

47. The individual action plan should be a guide back to work for the job-seekers, for example defining within which sectors the job-seekers should search for work. However, three fifths of the participants did not even know that they had an individual action plan. This result is a shortcoming considering the importance the individual action plan should have in the Activity Guarantee.

\subsection{Job search}

48. Around $90 \%$ of the participants were interested in taking a job at the time when they answered the questionnaire. If the participants' wishes are to be realised their search efforts are essential. Since February 2001 the restrictions on those who receive unemployment benefits are more explicit. To receive income support job-seekers must contribute to the making of an individual action plan and actively search for work. To receive UI benefit payment they also have to widen their geographical and professional search area after a period of 100 days of unemployment. One important task of the supervisors is to make these restrictions clear.

49. To investigate to what extent the participants searched for work, they were asked to estimate how many jobs they had applied for during the four-week period preceding the telephone inquiry: on average they had applied for two jobs. A majority $(60 \%)$ had not applied for any job at all. The search intensity was lower outside metropolitan areas ${ }^{17}$ and it significantly decreased with longer registration times at the PES office. Among those who started participating during 2000, 64\% had not applied for any job during the four-week period preceding the time of the survey, whereas among those who were registered as programme participants during 2002 that proportion was $47 \%$. Slightly less than one third of those that did not apply for a single job worked. ${ }^{18}$ It must be considered a failure that the other two-thirds did not apply for any job.

50. Previous studies show that search intensity among participants in labour market programmes is lower than among the openly unemployed (Calmfors et al., 2001). The Activity Guarantee should imply increased search efforts promoted by the PES offices. To get a picture of the possible change in search effort when participating in the Activity Guarantee, the participants were asked about their search efforts before and after entering the programme. Three out of five applied for work to the same extent as they did before entering the programme. Before entering the programme most of the participants did not search for work outside commuting range. Participation in the Activity Guarantee does not seem to have changed their behaviour.

\section{Stockholm, Göteborg, and Malmö.}

18. More precisely, they participated in activities which are considered regular employment in the UI benefit payment regulations and, hence, if the duration is long enough, requalifies for UI benefits (see note 24). 
51. A third of the respondents did not search for work which they did not have any prior experience of or education for before entering the programme. That proportion increased to almost $40 \%$ when entering the programme. The proportion that searched for such jobs to a high extent did not change significantly after entering the programme. Only one fifth had been recommended by their supervisor to widen their geographical search area. Slightly less than three fifths had been recommended to widen their search by professional area.

\subsection{The participants' assessment of the Activity Guarantee}

52. A majority of the participants (63\%) were motivated to participate in the programme. However, more than half of them would choose not to participate if it did not provide them with income support. Motivation seems to decrease with higher age. One possible explanation could be that the participants' expectations of getting a job decreases when they get older.

53. The participants in the Activity Guarantee were motivated to take a job and their programme participation does not seem to have substantially changed their motivation. About one third of the participants believed that their chances to get a job had increased through their participation in the Activity Guarantee. This opinion was more common among participants in metropolitan areas. The majority, however, did not think that participating had had any effect on their chances to get a job.

54. Almost three out of four were very or fairly content with the programme. Only about $10 \%$ were very dissatisfied. The dissatisfaction seems to be larger among those that had participated a long time. One possible explanation could be that those having participated longer on average stood farther away from the labour market and felt that participation in the Activity Guarantee would not help them to get a job.

\subsection{Summary}

55. The job-seekers participating fit the visible characteristics of long-term unemployed in special need of assistance: compared to others registered at the PES offices, participants had a higher mean age and a higher share have a disability and a low level of formal training respectively.

56. An important programme feature is intensive counselling and a higher level of monitoring of the participants' job search. However, almost half of the participants met with their personal counsellor less than once a month.

57. The participants' level of interest in finding a job was fairly high, but their job-search intensity was not very high. Almost one-third of those who were very interested in taking a job and more than half of those who were fairly interested had not applied for a single job during the four weeks preceding the interview. Most participants applied for jobs to the same extent that they did before entering the programme. They continued to search for a job within the same geographical area as prior to participating. The same goes for the extent to which participants searched for jobs that they had no prior experience of or were not trained to do.

58. As a whole, the participants were content with the Activity Guarantee. Their assessment of the programme's ability to improve their status in the labour market was, however, not as good as that of participants of other ALMPs. ${ }^{19}$

19. The comparison is made with the results from an earlier follow-up - of job-seekers having participated in programmes in 1996 - made by the LMB in 1997. 


\section{A first evaluation of treatment effects}

59. The Activity Guarantee was introduced in August 2000. Hägglund (2002) estimated treatment effects for participants entering the programme in October or November 2000 using matching methods. The results indicate that participants found jobs at a higher rate than a control group of non-participants: the probability of being employed twelve months after the programme start was $35 \%$ higher for the participants. However, this positive effect was entirely due to a higher probability of finding a job with an employment subsidy. ${ }^{20}$ The Activity Guarantee did not increase the probability of finding a non-subsidised job. Moreover, participants who found unsubsidised jobs returned to unemployment at a higher rate than non-participants.

60. The interpretation of Hägglund's results, even if taken at face value, raises a number of issues. First, the group of participants he considered entered the programme only a couple of months after the programme was launched. It cannot be taken for granted that the effects would be the same for participants entering later, when the initial period of trial (and error?) was over. Second, the follow-up horizon was short. This does not give rise to any special problems as long as we consider the job-search aspect of the programme. However, if the closer contact between the case workers and the participants enabled the case workers to identify the "correct" individuals to be placed in subsidised employment programmes, the positive effect of this would emerge with a substantial lag (if there was a positive effect on the postprogramme employment probability). ${ }^{21}$ Third, Hägglund points out that there is evidence to suggest that participants used relatively less informal search channels than did non-participants. To the extent that this was a result of increased monitoring rather than counselling, it may indicate that participants were forced to devote too much time to inefficient search methods. ${ }^{22}$

61. A general problem, finally, concerns the possibilities to evaluate the programme at all with conventional methods. Fredriksson and Johansson (2003) point out that the generic problem dealt with in the evaluation literature concerns a situation when "treatment" is offered only once. This is not a good description of the Activity Guarantee (or any other of the major Swedish ALMPs). Instead, programme participation can be thought of as a dynamic process where programme start is stochastic. The analysis in Fredriksson and Johansson (2003) shows that this has serious implications for the possibilities to estimate causal programme effects. The problem arises because in order to estimate a causal treatment effect, one needs a comparison group of persons who were never treated. However, finding such a comparison group involves conditioning on future events, since programme start can happen at any point in time. In general, those who never participate in a programme to a large extent have found a job. Hence, many popular estimators, by construction, have an over-representation of job finders in the control group, and, hence, will tend to give downward biased estimates of programme effects. ${ }^{23}$

62. The discussion above is applicable to the matching methods used by Hägglund (2002). Hence, in addition to the issues spelt out above concerning the results taken at face value, there is reason to suspect that his estimates of the effects of the Activity Guarantee are downward biased.

20. A number of employment subsidy programmes, targeted at the long-term unemployed, were introduced in the late 1990s.

21. However, if case workers identify those for whom referral will have a motivation effect, this impact would not be much lagged.

22. In the light of our survey evidence on job-search activities in the Activity Guarantee, reported in Section 5.4, the idea of time-constrained substitution of search methods does not seem overly plausible.

23. Note that this problem is a pure sampling problem that has got nothing to do with ordinary selection problems, with selection into programmes being driven by unobserved variables simultaneously affecting the results of programme participation. 


\section{Concluding comments}

63. The Activity Guarantee for the long-term unemployed, introduced in August, 2000, entails a number of components but one of the more important ones is that the programme is supposed to involve increased counselling and monitoring. According to evidence from programme evaluations - both of Swedish programmes and programmes in other countries - this should improve the job-finding rate of participants. A few months later, new UI benefit rules were introduced that meant that participation in ALMPs no longer re-qualifies for a new UI benefit period. Job-seekers facing benefit exhaustion should instead take part in the Activity Guarantee.

64. It is as yet too early to evaluate the Activity Guarantee - the time span since it was launched is relatively short and the Swedish labour market has been relatively stable since the late 1990s. A few things can, however, be said about the programme. First, it is clear that the programme is not a guarantee in the sense that all long-term unemployed enter it: only a relatively small fraction of those with long spells in open unemployment have entered the programme. Participation in traditional labour market policy measures has been much more common. Non-participants in the Activity Guarantee may maintain income support over long periods through participation in subsidised employment in the private sector, which still generates new UI entitlements ${ }^{24}$ or participation in series of traditional measures with only short gaps between one measure and the next. The role of these alternatives deserves attention. Second, a large fraction of the participants seem to meet their personal counsellors relatively seldom. Furthermore, far from all of the participants $(66 \%)$ said that the activity had been full-time. This casts some doubts on the content of increased counselling and monitoring in the programme. Third, according to our survey evidence, there are no clear signs of increased search activity among the participants. This would be consistent with the evidence on monitoring and counselling. Fourth, evidence from an early evaluation does not indicate any positive effects on the job-finding rate of participants. Finally, the participants were content with the Activity Guarantee. Whether this reflects an assessment of the programme content or the fact that the programme provides the participants with income support is, however, not entirely clear.

24. Employment subsidized through the "General Employment Subsidy", which covers 50\% of wage costs, can still renew eligibility for UI benefits: this is not possible for other types of employment subsidy which cover a higher proportion of wage costs. 
DELSA/ELSA/WD/SEM(2004)1

\section{REFERENCES}

AMS (1999), "Arbetsmarknadsverket I 2000-talet. Arbetsmarknadspolitiken, arbetsmarknadsverket och verksamheten i början av 2000-talet", rapport till regeringen 1999-12-17, National Labour Market Board, Stockholm.

AMS (2001), "Rapport om aktivitetsgarantin", rapport till regeringen, 2001-02-08, National Labour Market Board, Stockholm.

ASHENFELTER, O., D. ASHMORE, and O. DESCHENES (1999), "Do unemployment insurance recipients actively seek work? Randomized trials in four U.S. states", Working Paper 6982, NBER.

VAN DEN BERG, G., and B. VAN DER KLAAUW (2001), "Counseling and monitoring of unemployed workers: theory and evidence from a controlled social experiment", Working Paper 2001:11, IFAU, Uppsala.

VAN DEN BERG, G., and K. RICHARDSON (2002), "The effect of vocational employment training on the individual transition rate from unemployment to work", Working Paper 2002:8, IFAU, Uppsala.

CALMFORS, L., A. FORSLUND, and M. HEMSTRÖM (2001), "Does active labour market policy work? Lessons from the Swedish experiences", Swedish Economic Policy Review 8, 61-124.

CARLING, K., P.-A. EDIN, A. HARKMAN, and B. HOLMLUND (1996), "Unemployment duration, unemployment benefits, and labor market programs", Journal of Public Economics 59, 313-334.

CARLING, K., B. HOLMLUND, and A. VEJSIU (2001), "Do Benefit Cuts Boost Job Finding? Swedish Evidence from the 1990s", Economic Journal 111, 766-90.

Ds 1999:54, Samverkan för färre bidrag och fler i jobb, Ministry of Social Affairs, Stockholm.

Ds 1999:58, "Kontrakt för arbete. Rättvisa och tydliga regler i arbetslöshetsförsäkringen", Ministry of Industry, Employment and Communications, Stockholm.

FREDRIKSSON, P., and B. HOLMLUND (2003), "Improving incentives in unemployment insurance: A review of recent research", Working Paper 2003:5, IFAU, Uppsala.

FREDRIKSSON, P, AND P JOHANSSON (2003), "Program evaluation and random program starts", Working Paper 2003:1, IFAU, Uppsala.

FRÖBERG, D, and K PERSSON (2002), "Genomförandet av aktivitetsgarantin", Rapport 2002:2, IFAU, Uppsala.

FRÖBERG, D, and L LINDQVIST (2002), "Deltagarna i aktivitetsgarantin", Rapport 2002:11, IFAU, Uppsala.

GOVERNMENT BILL 1999/2000:98, Förnyad arbetsmarknadspolitik för delaktighet och tillväxt. 
DELSA/ELSA/WD/SEM(2004)1

GOVERNMENT BILL 1999/2000:139, En rättvisare och tydligare arbetslöshetsförsäkring.

HÄGGLUND, P (2002), "Första året med aktivitetsgarantin", Ura 2002:2, National Labour Market Board, Stockholm.

LAYARD, R, S NICKELL, and R JACKMAN (1991), Unemployment: macroeconomic performance and the labour market, Oxford University Press.

LUNDIN, M (2000), "Anställningsstödens implementering vid arbetsförmedlingarna", Stencilserie 2000:4, IFAU, Uppsala.

LUNDIN, M (2001), "Hur fungerar anställningsstöden?", Forskningsrapport 2001:9, IFAU, Uppsala.

MEYER, B (1995), "Lessons from the U.S. unemployment insurance experiments", Journal of Economic Literature XXXIII, 91-131.

MORTENSEN, D (1977), "Unemployment insurance and job search decisions", Industrial and Labor Relations Review 30, 505-517.

SIANESI, B (2001a), "An evaluation of the active labour market programmes in Sweden", Working Paper 2001:5, IFAU, Uppsala.

SIANESI, B (2001b), "The Swedish active labour market programmes in the 1990s: Overall effectiveness and differential performance", Swedish Economic Policy review 8, 133-169.

THOURSIE, A (1998), Studies on Unemployment Duration and on the Gender Wage Gap, Dissertation series 35, Swedish Institute for Social Research, Stockholm University. 


\section{OECD SOCIAL, EMPLOYMENT AND MIGRATION WORKING PAPERS}

Most recent releases are:

No. 15 LOW FERTILITY RATES IN OECD COUNTRIES: FACTS AND POLICY RESPONSES (2003) Joëlle Sleebos

No. 14 NATIONAL VERSUS REGIONAL FINANCING AND MANAGEMENT OF UNEMPLOYMENT AND RELATED BENEFITS: THE CASE OF CANADA (2003) David Gray

No. 13 THE COMPETITIVE MARKET FOR EMPLOYMENT SERVICES IN THE NETHERLANDS (2003) Ludo Struyven and Geert Steurs

No. 12 TOWARDS SUSTAINABLE DEVELOPMENT: THE ROLE OF SOCIAL PROTECTION (2003) Marco Mira d'Ercole and Andrea Salvini

No. 11 INDIVIDUAL CHOICE IN SOCIAL PROTECTION: THE CASE OF SWISS PENSIONS (2003) Monika Queisser and Edward Whitehouse

No. 10 IMPROVING WORKERS' SKILLS: ANALYTICAL EVIDENCE AND THE ROLE OF THE SOCIAL PARTNERS (2003) Wooseok Ok and Peter Tergeist

No. 9 THE VALUE OF PENSION ENTITLEMENTS: A MODEL OF NINE OECD COUNTRIES (2003) Edward Whitehouse

No. 8 FINANCIAL RESOURCES AND RETIREMENT IN NINE OECD COUNTRIES: THE ROLE OF THE TAX SYSTEM (2003) Edward Whitehouse and Gordon Keenay

No. 7 THE IMPACT OF PARENTAL LEAVE ON MATERNAL RETURN TO WORK AFTER CHILDBIRTH IN THE UNITED STATES (2003) Sandra L. Hofferth and Sally C. Curtin

No. 6 SOCIAL POLICIES, FAMILY TYPES AND CHILD OUTCOMES IN SELECTED OECD COUNTRIES (2003) Sheila B. Kamerman, Michelle Neuman, Jane Waldfogel and Jeanne Brooks-Gunn

No. 5 CHILD LABOUR IN SOUTH ASIA (2003) Eric V. Edmonds

No. 4 CHILD LABOUR IN AFRICA (2003) Sonia Bhalotra

No. 3 LE TRAVAIL DES ENFANTS EN AMÉRIQUE LATINE (2003) Pierre-Emmanuel Couralet

No. 2 THE DETERMINANTS OF CHILD LABOUR: THEORY AND EVIDENCE (2003) Drusilla K. Brown, Alan V. Deardorff and Robert M. Stern

No. 1 CAREER INTERRUPTIONS DUE TO PARENTAL LEAVE: A COMPARATIVE STUDY OF DENMARK AND SWEDEN (2003) Elina Pylkkänen and Nina Smith

Other series of working papers available from the OECD include:

\section{OECD HEALTH WORKING PAPERS}

Most recent releases are:

No. 9 HEALTH CARE SYSTEMS: LESSONS FROM THE REFORM EXPERIENCE (2003) Elizabeth Docteur

No. 8 PRIVATE HEALTH INSURANCE IN AUSTRALIA. A CASE STUDY (2003) Francesca Colombo and Nicole Tapay

No. 7 MOST RECENT RELEASES ARE: EXPLAINING WAITING-TIMES VARIATIONS FOR ELECTIVE SURGERY ACROSS OECD COUNTRIES (2003) Luigi Siciliani and Jeremy Hurst

No. 6 TACKLING EXCESSIVE WAITING TIMES FOR ELECTIVE SURGERY: A COMPARISON OF POLICIES IN 12 OECD COUNTRIES (2003) Jeremy Hurst and Luigi Siciliani

Recent available working papers can be found on the OECD website: www.oecd.org. 
DELSA/ELSA/WD/SEM(2004)1

\section{RECENT RELATED OECD PUBLICATIONS:}

ASSET BUILDING AND THE ESCAPE FROM POVERTY: A NEW WELFARE POLICY DEBATE (2003)

OECD EMPLOYMENT OUTLOOK 2003 - TOWARDS MORE AND BETTER JOBS (2003)

MANAGING DECENTRALISATION: A NEW ROLE FOR LABOUR MARKET POLICY (2003)

COMBATING CHILD LABOUR: A REVIEW OF POLICIES (2003)

AGEING AND EMPLOYMENT POLICIES - SWEDEN (2003)

AGEING AND EMPLOYMENT POLICIES - BELGIUM (2003) (French version only with Executive summary in English)

A DISEASE-BASED COMPARISON OF HEALTH SYSTEMS - What is Best and at What Cost? (2003)

TRANSFORMING DISABILITY INTO ABILITY: Policies to Promote Work and Income Security for Disabled People (2003)

BABIES AND BOSSES:Reconciling Work and Family Life, Volume 1 Australia, Denmark and the Netherlands (2003)

PRIVATE FINANCE AND ECONOMIC DEVELOPMENT (2003)

ENTREPRENEURSHIP AND LOCAL DEVELOPMENT: PROGRAMME AND POLICY RECOMMENDATIONS (2003)

THE NON-PROFIT SECTOR IN A CHANGING ECONOMY (2003)

SOCIETY AT A GLANCE (2002)

TOWARDS ASIA'S SUSTAINABLE DEVELOPMENT - The Role of Social Protection (2002)

MEASURING UP: IMPROVING HEALTH SYSTEMS PERFORMANCE IN OECD COUNTRIES (2002)

BENEFITS AND WAGES - OECD Indicators (2002)

TRENDS IN INTERNATIONAL MIGRATION: SOPEMI 2002 (2002)

KNOWLEDGE AND SKILLS FOR LIFE: First Results from PISA 2000 (2001)

AGEING AND INCOME: Financial Resources and Retirement in 9 OECD Countries (2001)

HEALTH AT A GLANCE (2001)

SOCIETY AT A GLANCE: OECD Social Indicators (2001)

INNOVATIONS IN LABOUR MARKET POLICIES: The Australian Way (2001)

OECD EMPLOYMENT OUTLOOK July 2002 (published annually)

For a full list, consult the OECD On-Line Bookstore at www.oecd.org, or write for a free written catalogue to the following address:

OECD Publications Service

2, rue André-Pascal, 75775 PARIS CEDEX 16

or to the OECD Distributor in your country 